\title{
Q\&A: One giant leap for art
}

Astronaut Alan Bean stepped down onto the lunar surface during the 1969 Apollo 12 mission, but left NASA in 1981 to devote himself to painting. With exhibitions of his work taking place this year to celebrate the 40th anniversary of the first Moon landing, he tells Nature how he attempts to convey his lunar experience.

\section{How did you become a painter?}

Accidentally, I ended up becoming the first artist in history to go anywhere else beyond Earth and paint it. When I got ready to leave NASA, half of the astronauts wondered if this was a worthwhile thing to do with my life. And the others weren't sure. Now they all like it. They can see that I'm preserving one of the great adventures of humankind in a way that is meaningful for them.

\section{Why are your Moon paintings so colourful?}

The Moon isn't colourful - it's grey. The sky is black and we run around in white suits. My first paintings were mostly grey, because that's what the Moon is. Now I realize the artist's job is not to reproduce reality.

\section{Why do you use Moon dust} and tools from your mission? The Moon was pretty rugged, so I wanted to put some texture in. The first texture I added was with normal art tools. Then I said "Why am I doing this? I've got Moon tools" - I've got the hammer I had on the Moon; I've got Moon boots.

A friend in charge of a museum requested the Apollo 12 command module, and they shipped it to him in this huge box. He looked in the box and a lot of the charred heat shield had come off, so he vacuumed it up and sent it to me. I put that in there. Then

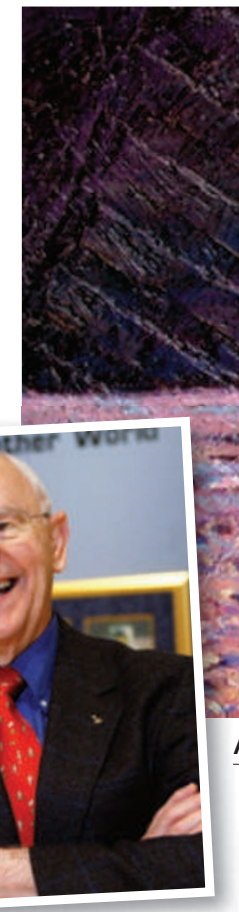
on me that they're dirty with Moon dust from the Ocean of Storms. I started cutting them up and put them in too.

\section{What are you working on now?}

My current painting tells the story of when I fell down on the Moon and Pete Conrad (Apollo 12's commander) came over and lifted me up with one finger. I'm lying on my butt leaning back and I've got my left arm out.

\section{Voyaging to discovery, alone}

\section{The Age of Wonder: \\ How the Romantic Generation Discovered the Beauty and Terror of Science by Richard Holmes HarperPress/Pantheon: 2008/2009. 380 pp/576 pp. £25/\$40}

Everyone knows how to be a great scientist. First, you have to be really smart. Having awed your school science teacher is good. Humbling all the others at university is even better. Then you need to find a place where you can let your solitary genius come out. You might escape to a coffee shop to think; or if your parents are really rich, to a trendy loft apartment or, better still, a remote and windswept cottage. There you will engage in the next and most crucial of stages: the creative torture.

There is an art to this. It is important your torment doesn't end too quickly - otherwise you'd show you had been working on a problem that was too simple. Yet if the torment never ends, you'll have nothing to tell anyone about and will remain unknown. After some time, ideally a few months, you get to have a 'eureka moment'. At that point all you have to do is write up your discovery, accept the plaudits, be it from department colleagues or the Swedish Academy, and then if you can bear it, repeat from the start.

We smile at this recap but the basic vision science as an endeavour of individual creative genius that explodes in an instant of discovery - is one we take for granted. Yet, as Richard Holmes describes in his new book The Age of Wonder, it was not always so. Most founders of modern science in the 1600s, such as Isaac Newton, rarely saw their work this way. For them the process was clinical, building on a slow accumulation of insight.

The big shift took place in the decades around 1800 , a period called the Romantic era. 